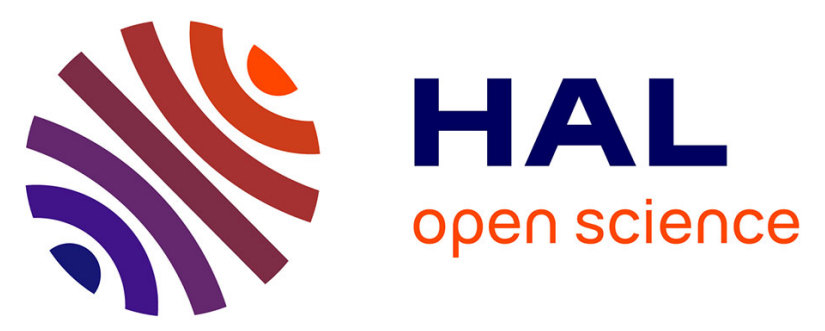

\title{
A high protein, low fat diet is more effective at improving blood pressure and triglycerides in calorie-restricted obese individuals with newly diagnosed type 2 diabetes
}

Antonis Zampelas, Emilia Papakonstantinou, Despina Triantafillidou, Demosthenes Panagiotakos, Anastasios Koutsovasilis, Michalis Saliaris, Athanasios Manolis, Andreas Melidonis

\section{- To cite this version:}

Antonis Zampelas, Emilia Papakonstantinou, Despina Triantafillidou, Demosthenes Panagiotakos, Anastasios Koutsovasilis, et al.. A high protein, low fat diet is more effective at improving blood pressure and triglycerides in calorie-restricted obese individuals with newly diagnosed type 2 diabetes. European Journal of Clinical Nutrition, 2010, n/a (n/a), pp.n/a-n/a. 10.1038/ejcn.2010.29 . hal00516535

\section{HAL Id: hal-00516535 \\ https://hal.science/hal-00516535}

Submitted on 10 Sep 2010

HAL is a multi-disciplinary open access archive for the deposit and dissemination of scientific research documents, whether they are published or not. The documents may come from teaching and research institutions in France or abroad, or from public or private research centers.
L'archive ouverte pluridisciplinaire HAL, est destinée au dépôt et à la diffusion de documents scientifiques de niveau recherche, publiés ou non, émanant des établissements d'enseignement et de recherche français ou étrangers, des laboratoires publics ou privés. 
Manuscript Number: 2009EJCN0570R

A high protein, low fat diet is more effective at improving blood pressure and triglycerides in calorie-restricted obese individuals with newly diagnosed type 2 diabetes Emilia Papakonstantinou, ${ }^{\mathrm{a}, \mathrm{b}}$, MS, RD; Despina Triantafillidou ${ }^{\mathrm{c}}$, BS; Demosthenes B. Panagiotakos $^{\mathrm{a}}, \mathrm{PhD}$; Anastasios Koutsovasilis ${ }^{\mathrm{c}}, \mathrm{MD}$; Michalis Saliaris ${ }^{\mathrm{d}}, \mathrm{MD}$; Athanasios Manolis $^{\mathrm{c}}, \mathrm{MD}, \mathrm{PhD}$; Andreas Melidonis ${ }^{\mathrm{c}}, \mathrm{MD}, \mathrm{PhD}$; Antonis Zampelas ${ }^{\mathrm{e}}, \mathrm{PhD}$.

${ }^{\mathrm{a}}$ Department of Dietetics and Nutrition Sciences, Harokopio University, Athens, Greece

${ }^{\mathrm{b}}$ Second Department of Internal Medicine, Research Institute and Diabetes Center, Athens University, Attikon University Hospital, Haidari, Greece.

${ }^{\mathrm{c}}$ Tzanio General Hospital, Piraeus, Greece.

${ }^{\mathrm{d}}$ Nikaia General Hospital, Piraeus, Greece.

${ }^{\mathrm{e}}$ Unit of Human Nutrition, Department of Food Science and Technology, Agricultural University of Athens, Athens, Greece

This work was funded by Novartis Hellas, S.A.C.I., Metamorfossi, Greece

\section{Corresponding Author:}

Antonis Zampelas

Associate Professor in Human Nutrition

Unit of Human Nutrition, Department of Food Science and Technology

Agricultural University of Athens

Iera Odos 75, Athens 11855, Greece 
Tel: $+30210-5294701$

Fax : $+30210-5294701$

Email: azampelas@aua.gr

Running Title: Diet and coronary heart disease risk factors

Key words: diet, protein, coronary heart disease, diabetes, obesity

Abbreviations:

HP: high protein diet

LP: low protein diet

HP-LF: high protein, low fat

LP-HF: low protein, high fat

BMI: body mass index

TC: total cholesterol

HDL: high density lipoprotein

LDL: low density lipoprotein

TG: triglycerides

BP: blood pressure

DM2: type 2 diabetes mellitus

RCT: randomized controlled trials

HbA1c: haemoglobin A1c

HOMA: homeostasis model assessment

AUC: area under the curve

IAUC: incremental area under the curve 


\section{ABSTRACT}

Background / Objectives: There is controversy over dietary protein's effects on cardiovascular disease risk factors in diabetic subjects. It is unclear whether observed effects are due to increased protein or reduced carbohydrate content of the consumed diets. The aim of the present study was to compare the effects of two diets differing in protein to fat ratios on cardiovascular disease risk factors.

Subjects / Methods: Seventeen obese (BMI ranging from 31-45 kg/m²), volunteers with type 2 diabetes (DM2), 46 \pm 3 years of age, consumed two diets, each for 4 weeks, with 3 weeks washout period in a random, blind, cross-over design. The diets were: 1) a high protein, low fat diet (HP-LF, 30\% protein, 50\% carbohydrates, $20 \%$ fat) and 2) a low protein, high fat diet (LP-HF, 15\% protein, 50\% carbohydrates, 35\% fat). Their effects on fasting glycaemic control, lipid levels, and blood pressure, and on postprandial glucose and insulin responses following a standard test meal at the beginning and end of each dietary intervention were investigated.

Results: Both diets were equally effective at promoting weight loss, fat loss, and improving fasting glycaemic control, total cholesterol and low-density lipoprotein cholesterol; but the HP-LF diet decreased to a greater extent triglyceride levels $(\mathrm{P}=0.04)$ compared to the LP-HF diet. HP-LF diet improved significantly both systolic and diastolic blood pressure compared to the LP-HF diet $(\mathrm{P}<0.001$ and $\mathrm{P}<0.001$, respectively). No differences were observed in postprandial glucose and insulin responses.

Conclusions: A protein to fat ratio of 1.5 in diets significantly improves blood pressure and triglycerides concentrations in obese individuals with DM2. 


\section{INTRODUCTION}

Prevalence of type 2 diabetes (DM2) is reaching epidemic proportions worldwide. Although nutrition has always had an integral role in diabetes management, the optimal diet for people with diabetes continues to be evaluated.

It is unclear whether dietary protein and/or fatty acids have an impact on glycaemic control. Studies have reported that dietary protein causes a moderate decrease in postprandial glucose levels of diabetic subjects (Sharman et al 2004, Volek et al 2004), which may be due to a synergistic effect of carbohydrates and proteins in stimulating insulin secretion (Claessens et al 2008, van Loon et al 2003). Results from a meta-analysis of randomized clinical trials showed that in 9 out of 11 , there were greater reductions in hyperglycaemia and glycated haemoglobin with high than low protein diets (Kirk et al 2008). However, the Attica Study investigators showed that dietary protein does not affect plasma glucose or insulin in healthy or diabetic subjects (Papakonstantinou et al 2005). On the other hand, studies examining the effects of fatty acids on postprandial glucose and insulin concentrations in people with and without DM2 have produced contradicting results (Rasmussen et al 1996, Robertson et al 2002, Zampelas et al 1994).

In a previous crossover, randomized study, we compared the effects of two meals containing equal amounts of carbohydrates (50\% of total energy), but different protein to fat ratios on postprandial glucose and insulin responses of obese subjects with and without DM2 and reported no significant effects on these variables (Papakonstantinou et al In Press).

The aims of the present study therefore, was to investigate whether diets containing equal amounts of carbohydrates but different protein to fat ratios, have differential effects on indexes of glycemic control, blood lipids, and arterial blood pressure in obese individuals with DM2. 


\section{METHODS}

\section{Subjects}

Seventeen obese subjects with newly diagnosed type 2 diabetes mellitus (DM2) were recruited from the outpatient clinic of Tzanio General Hospital of Piraeus. This study included individuals aged 30-65 years with a fasting serum glucose concentration $\geq 7 \mathrm{mmol} / \mathrm{l}$ and a body mass index (BMI) between $30-45 \mathrm{~kg} / \mathrm{m}^{2}$. Health status was evaluated by complete medical examination by the study doctor. Patients that had been treated with diet, oral hypoglycemic agents or insulin were excluded, as well as those with proteinuria/ albuminuria, kidney disease, hematological abnormalities, liver disease, untreated hyper- or hypothyroidism, arrhythmias, heart disease, cancer, vascular disease, or serious mental disorders. The study protocol, approved by the Human Ethics Committee of the Harokopio University and the Tzanio General Hospital of Piraeus, was fully explained to each subject before he/she provided written consent.

\section{Diets}

Diet histories and physical activity profiles were obtained using 24-hour recalls. Daily energy requirements were calculated with the Harris-Benedict equation (Harris and Benedict 1919). Intervention diets aimed at a $700 \mathrm{kcal} / \mathrm{d}$ energy deficit from the estimated energy requirements. All subjects were sedentary at baseline and were asked to continue their usual physical activity levels and to abstain from drinking alcohol throughout the study.

The prescribed diets were: 1) a high protein, low fat (HP-LF) diet (30\% protein, $50 \%$ carbohydrates, $20 \%$ fat) and 2) a low protein, high fat (LP-HF) diet (15\% protein, $50 \%$ carbohydrates, 35\% fat). For each diet, the percentage of energy derived from carbohydrate was matched. The LP-HF diet was designed according to the recommendations of the 
American Diabetes Association (2008). Meals on both diets were composed primarily of lean protein sources (i.e. lean meat, poultry, fish, and eggs), and low-fat dairy products (i.e. $1 \%$ fat milk, nonfat yogurt, low-fat cheese with $10 \%$ fat). The additional fat in the LP-HF diet came primarily from olive oil. The diets were designed to contain more than 25 grams of fiber and less than $10 \%$ saturated fat. Diets were analyzed with the software Diet Analysis Plus (version 6.1, ESHA Research, OR, USA). To achieve the composition of the prescribed diets, the subjects were advised to follow fixed-menu plans and were supplied with a meal replacement (Optifast ${ }^{\circledR}$ by Novartis Hellas, S.A.C.I., Metamorfossi, Greece), which replaced breakfast and lunch, and made up $26 \%$ of their energy intake. Meal replacements were provided at 2 weekly intervals when the subjects visited the Tzanio Hospital for dietary counseling. Food and liquid scales were provided to all participants. The dietitian gave detailed information to subjects about the dietary protocol and on how to keep daily weighed food records. The subjects' body weights and food records were monitored every two weeks, and dietary adjustments were made if needed (Table 1). The food records were analyzed with the use of Diet Analysis Plus software (version 6.1, ESHA Research, OR, USA). Recipes were entered as proportions of the original ingredients. The database has been extensively modified to include new foods and recipes.

\section{Experimental protocol}

\section{Experiment 1 - diet effects on indices of metabolic control}

The study followed a cross-over design. Subjects were randomly assigned to begin the study with either the HP-LF or LP-HF diet; consuming the first diet for 4 weeks (weeks 0 to 4), followed by 3 weeks of free diet without restrictions (wash out period), and then were switched to the second diet for another 4 weeks (weeks 7 to 11). 
Subjects visited the clinic between 8:30 and 9:30 am at weeks 0,4, 7, and 11 after a 12 hour fast and avoidance of alcohol and exercise. Fasting venous blood samples were collected for analysis of total cholesterol (TC), high density lipoprotein (HDL) cholesterol, low density lipoprotein (LDL) cholesterol, triglycerides (TG), plasma glucose and insulin concentrations and haemoglobin A1c (HbA1c).

\section{Experiment 2 - acute diet effect on postprandial plasma glucose and insulin levels}

Immediately after the collection of fasting blood samples, all subjects consumed the same standard mixed meal, tested and used in a previous study (Papakonstantinou et al In Press), in 15-20 minutes, at the beginning and end of each dietary intervention (for 4 times total) (Table 1). Blood samples were taken every 30 minutes for a total of 180 minutes for measurement of postprandial glucose and insulin concentrations in order to examine the effects of the tested diets on postprandial glucose and insulin responses following a standard test meal which resembled physiological composition of a typical breakfast.

\section{Measurements}

Height, weight, waist and hip circumference were measured in accordance with World Health Organization standards (1989) and BMI was calculated. Fat mass and fat-free mass were assessed by multifrequency bioimpedance (BIA, Bodystat 500, Bodystat Ltd, Douglas, Isle of Man, British Isles). BIA measurements were carried out with the patient lying in a supine position on a flat, nonconductive bed. Percent body fat was calculated by using the manufacturer's software. 
Blood pressure (BP) was measured twice at each visit with the use of a standard mercury sphygmomanometer after the patients had been sitting for 15 minutes. The mean of two measurements was recorded.

\section{Biochemical analysis}

Plasma glucose concentrations were measured by the AEROSET c8000 analyzer (Abbott, Chicago, IL, USA) using the glucose oxidase method. Insulin levels were assayed by microparticle enzyme immunoassay using the Abbot AxSYM insulin assay (Chicago, IL, USA). Glycated haemoglobin (\% HbA1c) was measured with the use of RX Daytona analyzer (Randox Laboratories, MA, USA). Creatinine, urea, uric acid, TG, TC and HDL cholesterol were measured by the AEROSET/ARCHITECT c8000 System (Abbott, Chicago, IL, USA). LDL cholesterol was calculated (Friedewald et al 1972). Insulin resistance was assessed by the calculation of the homeostasis model assessment (HOMA-R) approach [fasting glucose $(\mathrm{mmol} / \mathrm{l}) \mathrm{x}$ fasting insulin $(\mu \mathrm{UI} / \mathrm{ml}) / 22.5$ ] and the formula by Matsuda and Defronzo $[10,000 /$ the square root of (fasting glucose $(\mathrm{mg} / \mathrm{dl}) \mathrm{X}$ fasting insulin $(\mu \mathrm{U} / \mathrm{ml}) \mathrm{X}$ (mean two hour postprandial glucose from Experiment $2 \mathrm{X}$ mean two hour postprandial insulin from Experiment 2], which reflects insulin sensitivity in the post-absorptive period (Matsuda and DeFronzo 1999). This formula was used previously in mixed meal studies and correlates well with insulin sensitivity (Dimitriadis et al 2006). HOMA values $>2.5$ are considered indicative of insulin resistance, as suggested in the Bruneck Study (Bonora et al 1998). 


\section{Statistical Analysis}

Statistical analysis was performed by using SPSS for WINDOWS 13.0 software (SPSS, Chicago, IL, USA). Baseline characteristics were compared with Student's t- test for normally distributed data and with Mann-Whitney test for skewed data. Calculations of areas under the curve for plasma glucose and insulin responses were based on the trapezoid rule. The effect of test meal on blood glucose and insulin levels and of the diet on other variables was analyzed in a repeated measures analysis of variance with time as the within-subjects factor and diet as the between-subjects factor. BMI was introduced in the model as covariate. When significant interactions of time-by-diet were found, paired $t$ tests were used to find where the differences lay. The study had $80 \%$ power $(\alpha=0.05)$ to detect differences between dietary groups of $2.6 \mathrm{~kg}$ in body weight and $0.28 \mathrm{mmol} / \mathrm{l}$ in fasting plasma glucose. Significance was set at $P<0.05$. All data are presented as means \pm SEMs unless stated otherwise.

\section{RESULTS}

\section{Experiment 1}

\section{Baseline characteristics and subject compliance with the diets}

Patients' baseline characteristics are presented in Table 2. At the entry time points (weeks 0,7$)$ of each diet, there were no significant differences in patients' BMI (33.8 \pm 1.3 vs. $33.3 \pm 1.3, \mathrm{P}=0.8)$ and HbA1c levels $(6.4 \pm 0.3$ vs. $6.5 \pm 0.2, \mathrm{P}=0.9)$.

Both diets were well tolerated, with no adverse effects reported. The energy and macronutrient contents derived from the subjects' daily weighed food records are shown in Table 2 and did not differ from those of the prescribed diets $(P=0.6)$. Protein content was significantly higher and fat content was lower in the HP-LF than in the LP-HF $\operatorname{diet}(\mathrm{P}=0.02)$. 
The diets did not differ in saturated fat content $(P=0.7)$, but differed significantly in polyunsaturated fat $(\mathrm{P}=0.04)$ and monounsaturated fat $(\mathrm{P}=0.006)$.

\section{Body weight and composition}

After 4 weeks of energy restriction, both diets were equally effective at promoting weight loss. Fat mass was significantly lowered in both groups, with a greater decrease on the HP-LF diet than on the LP-HF diet group (P $<0.001$; Table 3). All main effects of diet were nonsignificant and there was no time-by-diet interaction for any of these variables.

\section{Blood Pressure}

Systolic BP was significantly lowered in both the LP-HF $(\mathrm{P}=0.002)$ and the HP-LF diet groups $(\mathrm{P}=0.002)$, with a greater decrease on the HP-LF diet $(\mathrm{P}<0.001)$ than on the LP-HF diet group (time-by-diet interaction, $\mathrm{P}=0.001$; main effect of diet, NS; Table 4). Diastolic BP was significantly decreased only in the HP-LF diet group $(\mathrm{P}<0.001$; main effect of diet, $\mathrm{P}=0.048$; time-by-diet interaction, $\mathrm{P}<0.001$; Table 4). As weight loss was similar in both groups, this suggests that the blood pressure lowering effect of the HP-LF diet was independent of weight loss.

\section{Serum Lipids}

Total cholesterol was significantly decreased in both the LP-HF diet $(\mathrm{P}=0.01)$ and the HP-LF diet groups $(\mathrm{P}=0.001$; main effect of diet, NS; time-by-diet interaction, NS; Table 4). LDL and HDL cholesterol were significantly decreased only in the HP-LF diet $(\mathrm{P}=$ 0.007 and $\mathrm{P}<0.001$, respectively $)$, but not in the LP-HF diet group $(\mathrm{P}=0.06$ and $\mathrm{P}=0.07$, respectively; main effect of diet, NS; time-by-diet interaction, NS; Table 4). Serum TG were significantly lowered in both the LP-HF $\operatorname{diet}(\mathrm{P}<0.001)$ and the HP-LF $\operatorname{diet}$ groups $(\mathrm{P}=$ 
0.01), with a greater decrease on the HP-LF diet $(\mathrm{P}=0.04)$ than on the LP-HF diet group (main effect of time $\mathrm{P}=0.004$; main effect of diet, NS; time-by-diet interaction, NS; Table 4).

\section{Fasting plasma glucose and insulin, insulin sensitivity, and glycated haemoglobin}

Both diets were equally effective at reducing fasting plasma glucose concentrations (main effect of time, $\mathrm{P}<0.001$; main effect of diet, NS; time-by-diet interaction, NS; Table 5, Figure 1), but fasting concentrations of plasma insulin remained unchanged.

HOMA-R and insulin sensitivity were significantly reduced only in the HP-LF group $(\mathrm{P}=0.02$ and $\mathrm{P}=0.001$, respectively; main effect of diet, NS; time-by-diet interaction, NS), but there was no difference between the two diets (Table 5). Although we did not expect to find any changes in HbAlc levels in such a short period of time, HbAlc was decreased by $0.2 \%$ for the LP-HF diet $(\mathrm{P}=0.2)$ and by $0.5 \%$ in the HP-LF group $(\mathrm{P}<0.001)$, but there was no significant difference between the diets after adjusting for weight loss.

\section{Experiment 2}

The areas under the curve (AUC) for glucose responses were significantly reduced only at 90-120 $\min (\mathrm{P}=0.028)$ and $120-150 \min (\mathrm{P}=0.029)$ after 4 weeks of both diets with no significant difference between them. The incremental area under the curve (IAUC) for glucose responses was significantly reduced in both diets $(\mathrm{P}=0.017)$ with no significant difference between them (main effect of time, $\mathrm{P}<0.001$; main effect of diet, NS; time-by-diet interaction, NS; Table 5, Figure 1). The AUCs for insulin responses did not differ after both diets, except at 120-150 min, which was significantly decreased only the HP-LF diet group (P $=0.027)$. The IAUC for insulin was significantly reduced only in the HP-LF diet group $(\mathrm{P}=$ 0.017); but there was no significant difference between the diets $(\mathrm{P}=0.1$; Figure 1). Peak glucose and insulin times were not significantly different within diet groups. 


\section{DISCUSSION}

The main findings of this study are that a HP-LF diet, with a protein to fat ratio of 1.5 , is more effective at improving blood pressure and triglycerides concentrations compared to a LP-HF diet; whereas both diets were equally effective at promoting fat loss and improving total cholesterol, LDL cholesterol and postprandial plasma glucose and insulin concentrations in obese subjects with newly-diagnosed type 2 diabetes. This is the first trial to our knowledge that examined the effects of diets containing equal amounts and quality of carbohydrates (50\% of total energy) on cardiovascular disease risk factors of obese, diabetic subjects.

\section{Experiment 1}

Results on weight loss and blood lipids were confirmed by a study comparing the effects of two carbohydrate-restricted diets (35\% of total energy) differing in protein and fat on weight loss, lipids, appetite regulation, and energy expenditure after test meals in overweight and obese subjects (Luscombe-Marsh et al 2005). In this study the HP-LF diet led to a better sparing of fat-free mass compared to the LP-HF diet, a finding confirmed by others (Piatti et al 1994), which may be significant for overweight and diabetes management.

Hypertension is one of the most important underlying risk factors for cardiovascular and all-cause mortality in the world today. In this study, the HP-LF diet lowered significantly more systolic and diastolic blood pressure compared to the LP-HF diet, independent from weight loss, sodium, or fibre content of the diet. Liu et al. (Liu et al 2002) in a meta-analysis of 9 cross-sectional studies, found a significant inverse association between dietary protein and blood pressure in both genders. It has been suggested that potentially protein intake could influence arterial BP through the actions of its constituent amino acids (Barre 2007, Ginsberg 
2000). In addition, insulin's role in hypertension may be somewhat more direct, with hyperinsulinemia potentially leading to salt and water retention (Storlien et al 1996). In this study, along with weight loss, HP-LF diet reduced hyperinsulinemia to a greater extent than LP-HF diet, which may provide one potential explanation for the beneficial results on BP observed only with the HP-LF diet. However, a possible mechanism could not be determined from the present data.

It is well known that carbohydrates are the major macronutrient affecting serum TG levels. In this study, a greater decrease in serum TG concentrations was observed with the HP-LF diet, independent of weight loss or carbohydrate content of the diet, compared with the LP-HF diet, but the mechanism for this effect cannot be determined from the present data. However, this observation is in line with other clinical trials (Farnsworth et al 2003, Skov et al 1999). It has also been suggested that a decrease in TG may increase HDL cholesterol concentrations (Garg et al 1988), but this was not confirmed in this or other studies (Skov et al 1999, Vazquez et al 1995). In addition, the HP-LF diet decreased LDL cholesterol concentrations more compared to the LP-HF diet, which is consistent with other studies (Parker et al 2002, Wolfe and Giovannetti 1991), a result possibly attributed to the lower saturated fat content of the HP-LF diet.

\section{Experiment 2}

In the present study, there was no significant difference in fasting or postprandial glucose concentrations between the LP-HF and the HP-LF diet groups, as has been suggested by other investigators (Parker et al 2002), which may reflect energy restriction and not macronutrient composition of the diet. However, in the present study, there was a trend for decreased postprandial insulin concentrations and improved insulin sensitivity only with the 
HP-LF diet, which is in agreement with others (Piatti et al 1994). Although, some have suggested that the monounsaturated (MUFA) and/or polyunsaturated (PUFA) fatty acid composition of a diet affects postprandial glucose and insulin responses (Robertson et al 2002; Joannic et al 1997, Petersen et al 1999), this has not been confirmed (Thomsen et al 1999, Thomsen et al 2003, Zampelas et al 1994). In the present study, the trend towards improved insulin sensitivity at the fasting and postprandial state was observed only with the diet containing lower amounts of MUFA and PUFA, a result possibly attributed to the protein content of the diet.

Strengths of this study include free-living patients and hence, results apply to real life conditions and investigation of several major cardiovascular disease risk factors. One of the limitations of this study was its short duration. In this study the wash-out period was designed to fall during a holiday season possibly explaining why the participants regained most of the weight lost; which was the goal of this study, and we encouraged the volunteers to have a free diet, but also shows the long-term importance of dietetic counselling and body weight monitoring. In addition, it only included newly diagnosed subjects with DM2; hence, their pancreatic function and/or degree of insulin resistance may vary from patients with established diabetes on antidiabetic medications and/or insulin. Moreover, microalbuminuria was not taken into account. The long-term effect of a diet containing $30 \%$ of calories from protein on renal function has to be evaluated.

In conclusion, the present study showed that a moderate low-calorie diet relatively high in protein and carbohydrates and low in fat can improve blood pressure and triglycerides concentrations. Future studies should also explore the efficacy and safety of long-term adherence to such dietary patterns. 


\section{REFERENCES}

World Health Organization (1989). Measuring obesity-classification and description of anthropometric data. Report on a WHO consultation of the epidemiology of obesity. Warsaw, 21-23 October 1987 World Health Organization: Copenhagen, Denmark.

American Diabetes Association (2008). Diagnosis and classification of diabetes mellitus. Diabetes Care 31: S55-60.

Barre DE (2007). The role of consumption of alpha-linolenic, eicosapentaenoic and docosahexaenoic acids in human metabolic syndrome and type 2 diabetes--a mini-review. $J$ Oleo Sci 56: 319-325.

Bonora E, Kiechl S, Willeit J, Oberhollenzer F, Egger G, Targher G et al (1998). Prevalence of insulin resistance in metabolic disorders: the Bruneck Study. Diabetes 47: 1643-1649.

Claessens M, Saris WH, van Baak MA (2008). Glucagon and insulin responses after ingestion of different amounts of intact and hydrolysed proteins. Br J Nutr 100: 61-69.

Dimitriadis G, Mitrou P, Lambadiari V, Boutati E, Maratou E, Panagiotakos DB et al (2006). Insulin action in adipose tissue and muscle in hypothyroidism. J Clin Endocrinol Metab 91: 4930-4937.

Farnsworth E, Luscombe ND, Noakes M, Wittert G, Argyiou E, Clifton PM (2003). Effect of a high-protein, energy-restricted diet on body composition, glycemic control, and lipid concentrations in overweight and obese hyperinsulinemic men and women. Am J Clin Nutr 78: 31-39.

Friedewald WT, Levy RI, Fredrickson DS (1972). Estimation of the concentration of lowdensity lipoprotein cholesterol in plasma, without use of the preparative ultracentrifuge. Clin Chem 18: 499-502.

Garg A, Bonanome A, Grundy SM, Zhang ZJ, Unger RH (1988). Comparison of a highcarbohydrate diet with a high monounsaturated-fat diet in patients with non-insulin dependent diabetes mellitus. $N$ Engl J Med 319: 829-834.

Ginsberg HN (2000). Insulin resistance and cardiovascular disease. J Clin Invest 106: 453458.

Harris JA, Benedict FG (1919). A biometric study of basal metabolism in man. Washington DC, Carnegie Institute of Washington (Publication 279).

Joannic JL, Auboiron S, Raison J, Basdevant A, Bornet F, Guy-Grand B (1997). How the degree of unsaturation of dietary fatty acids influences the glucose and insulin responses to different carbohydrates in mixed meals. Am J Clin Nutr 65 1427-1433. 
Kirk JK, Graves DE, Craven TE, Lipkin EW, Austin M, Margolis KL (2008). Restrictedcarbohydrate diets in patients with type 2 diabetes: a meta-analysis. J Am Diet Assoc 108: 91100 .

Liu L, Ikeda K, Sullivan DH, Ling W, Yamori Y (2002). Epidemiological evidence of the association between dietary protein intake and blood pressure: a meta-analysis of published data. Hypertens Res 25: 689-695.

Luscombe-Marsh ND, Noakes M, Wittert GA, Keogh JB, Foster P, Clifton PM (2005). Carbohydrate-restricted diets high in either monounsaturated fat or protein are equally effective at promoting fat loss and improving blood lipids. Am J Clin Nutr 81: 762-772.

Matsuda M, DeFronzo RA (1999). Insulin sensitivity indices obtained from oral glucose tolerance testing: comparison with the euglycemic insulin clamp. Diabetes Care 22: 14621470 .

Papakonstantinou E, Panagiotakos DB, Pitsavos C, Chrysohoou C, Zampelas A, Skoumas Y et al (2005). Food group consumption and glycemic control in people with and without type 2 diabetes: the ATTICA study. Diabetes Care 28: 2539-2540.

Papakonstantinou E, Triantafillidou D, Panagiotakos DB, Iraklianou S, Berdanier CD, Zampelas A (In Press). Protein content of single mixed meals does not influence glucose and insulin responses in obese individuals with or without type 2 diabetes. Human Nutrition and Dietetics.

Parker B, Noakes M, Luscombe N, Clifton P (2002). Effect of a high-protein, highmonounsaturated fat weight loss diet on glycemic control and lipid levels in type 2 diabetes. Diabetes Care 25: 425-430.

Petersen A, Marckmann P, Sanstrom B (1999). Postprandial lipoprotein, glucose and insulin responses after two consecutive meals containing rapeseed oil, sunflower or palm oil with or without glucose at the first meal. Br J Nutr 82: 97-104.

Piatti PM, Monti F, Fermo I, Baruffaldi L, Nasser R, Santambrogio G et al (1994). Hypocaloric high-protein diet improves glucose oxidation and spares lean body mass: comparison to hypocaloric high-carbohydrate diet. Metabolism 43: 1481-1487.

Rasmussen O, Lauszus FF, Christiansen C, Thomsen C, Hermansen K (1996). Differential effects of saturated and monounsaturated fat on blood glucose and insulin responses in subjects with non-insulin-dependent diabetes mellitus. Am J Clin Nutr 63: 249-253.

Robertson MD, Jackson KG, Fielding BA, Williams CM, Frayn KN (2002). Acute effects of meal fatty acid composition on insulin sensitivity in healthy post-menopausal women. $\mathrm{Br} J$ Nutr 88: 635-640. 
Sharman MJ, Gomez AL, Kraemer WJ, Volek JS (2004). Very low-carbohydrate and low-fat diets affect fasting lipids and postprandial lipemia differently in overweight men. $J$ Nutr 134: 880-885.

Skov AR, Toubro S, Ronn B, Holm L, Astrup A (1999). Randomized trial on protein vs carbohydrate in ad libitum fat reduced diet for the treatment of obesity. Int J Obes Relat Metab Disord 23: 528-536.

Storlien LH, Baur LA, Kriketos AD, Pan DA, Cooney GJ, Jenkins AB et al (1996). Dietary fats and insulin action. Diabetologia 39: 621-631.

Thomsen C, Rasmussen O, Lousen T, Holst JJ, Fenselau S, Schrezenmeir J et al (1999). Differential effects of saturated and monounsaturated fatty acids on postprandial lipaemia and incretin responses in healthy subjects. Am J Clin Nutr 69: 1135-1143

Thomsen C, Storm H, Holst JJ, Hermansen K (2003). Differential effects of saturated and monounsaturated fats on postprandial lipemia and glucagon-like peptide 1 responses in subjects with type 2 diabetes. Am J Clin Nutr 77: 605-611.

van Loon LJ, Kruijshoop M, Menheere PP, Wagenmakers AJ, Saris WH, Keizer HA (2003). Amino acid ingestion strongly enhances insulin secretion in patients with long-term type 2 diabetes. Diabetes Care 26: 625-630.

Vazquez JA, Kazi U, Madani N (1995). Protein metabolism during weight reduction with very-low-energy diets: evaluation of the independent effects of protein and carbohydrate on protein sparing. Am J Clin Nutr 62: 93-103.

Volek J, Sharman M, Gomez A, Judelson D, Rubin M, Watson G et al (2004). Comparison of energy-restricted very low-carbohydrate and low-fat diets on weight loss and body composition in overweight men and women. Nutr Metab (Lond) 1: 13.

Wolfe BM, Giovannetti PM (1991). Short-term effects of substituting protein for carbohydrate in the diets of moderately hypercholesterolemic human subjects. Metabolism 40: $338-343$.

Zampelas A, Murphy M, Morgan LM, Williams CM (1994). Postprandial lipoprotein lipase, insulin and gastric inhibitory polypeptide responses to test meals of different fatty acid composition: comparison of saturated, n-6 and n-3 polyunsaturated fatty acids. Eur J Clin Nutr 48: 849-858. 


\section{ACKNOWLEDGMENT}

The authors would like to thank Mrs Lavidopoulou Fani, head nurse of $1^{\text {st }}$ Pathology unit of Tzanio General Hospital of Piraeus for her invaluable help with patient evaluation, screening and blood drawing and Dr. Iraklianou Stella for her help with patient recruitment.

The authors' responsibilities were as follows - EP and AZ were responsible for the conception of the study, the perspective under which it was conducted and conducted the analyses; all authors: literature search and writing and editing the sections of the manuscript related to each author's area of expertise. None of the authors had a personal or financial conflict of interest. 


\section{Figure 1.}

Mean \pm SEM plasma glucose and insulin concentrations at baseline and at 30, 60, 90, 120, 150 , and 180 min postprandially following consumption of a standard test meal at the beginning and end of each dietary interventions with a high protein, low fat (HP-LF) and a low protein, high fat diet (LP-HF) diet for 4 weeks each. Repeated measures analysis of variance showed no significant differences and no time-by-diet interaction between the HPLF diet and LP-HF diet on postprandial glucose and insulin responses. There was a significant main effect of week for both glucose and insulin, $\mathrm{P}<0.001$. 


\begin{tabular}{|c|c|c|}
\hline Experiment 1 & $\begin{array}{c}\text { Low Protein, High Fat } \\
\text { Diet Group }(n=17)\end{array}$ & $\begin{array}{c}\text { High Protein, Low Fat } \\
\text { Diet Group }(n=17)\end{array}$ \\
\hline Energy (KJoule) & $6489 \pm 226^{4}$ & $6468 \pm 75$ \\
\hline Protein $(g)$ & $61 \pm 3$ & $117 \pm 0.7$ \\
\hline Protein $(\%)$ & $15 \%$ & $30 \%$ \\
\hline Carbohydrate (g) & $199 \pm 6$ & $196 \pm 3$ \\
\hline Carbohydrate (\%) & $50 \%$ & $50 \%$ \\
\hline Total Fat (\%) & $35 \%$ & $20 \%$ \\
\hline Total Fat (g) & $63 \pm 2$ & $35 \pm 1$ \\
\hline Saturated fat $(\mathrm{g})$ & $12 \pm 2$ & $11 \pm 1$ \\
\hline Monounsaturated fat (g) & $37 \pm 2$ & $16 \pm 2$ \\
\hline Polyunsaturated fat (g) & $9 \pm 0.3$ & $6 \pm 0.3$ \\
\hline Fiber $(\mathrm{g})$ & $32 \pm 2$ & $28 \pm 2$ \\
\hline Cholesterol (mg) & $152 \pm 7$ & $258 \pm 37$ \\
\hline Sodium (mg) & $1662 \pm 112$ & $1928 \pm 102$ \\
\hline Experiment 2 & \multicolumn{2}{|c|}{ High Protein Meal } \\
\hline Energy (KJoules) & \multicolumn{2}{|c|}{3109} \\
\hline Protein $(\%)$ & \multicolumn{2}{|c|}{$30 \%$} \\
\hline Protein $(\mathrm{g})$ & \multicolumn{2}{|c|}{55} \\
\hline Carbohydrate (\%) & \multicolumn{2}{|c|}{$51 \%$} \\
\hline Carbohydrate (g) & \multicolumn{2}{|c|}{95} \\
\hline
\end{tabular}




\begin{tabular}{|l|c|}
\hline Total fat (\%) & $19 \%$ \\
\hline Total Fat (g) & 16 \\
\hline Saturated fat (g) & 10 \\
\hline Monounsaturated fat (g) & 2 \\
\hline Polyunsaturated fat (g) & 4 \\
\hline Fiber (g) & $\bullet 112$ gr bread $^{6}$ \\
\hline Meal description & - 112 gr lettuce $^{3}$ \\
& $\bullet 120$ gr cheese $^{7}$ \\
& $\bullet 250$ ml juice $^{8}$ \\
\hline
\end{tabular}

${ }^{1}$ All values are means \pm SEM. Seven days of dietary data were analyzed at weeks 2 and 4 for each diet group.

${ }^{2} \mathrm{~A}$ meal replacement was included in fixed menu plan replacing breakfast and lunch (Optifast ${ }^{\circledR}$ by Novartis Hellas, S.A.C.I., Metamorfossi, Greece). The Optifast meal contains $201 \mathrm{kcal}, 17.5$ grams protein, 22.5 grams carbohydrates, 4.5 grams fat, 1.3 grams monounsaturated fat, 1.4 grams polyunsaturated fat, 1.15 grams linoleic acid, $195 \mathrm{mg}$ sodium, and 3.6 grams fiber.

${ }^{3}$ The standard test meal was created and analyzed using Diet Analysis Plus software (version 6.1, ESHA Research, OR, USA). Foods used: ${ }^{6}$ Kris-Kris ${ }^{\circledR}$, Katselis Sons S.A., Acharnai, Greece; 1 slice = 28 grams, $66.5 \mathrm{kcal}, 2$ grams protein, 13 grams carbohydrates, 1 gram fat; ${ }^{7}$ Trikalino light ${ }^{\circledR}$, Fage Company, Athens, Greece; 1 slice $=20$ grams, 47 kcal, 7 grams protein, 2 grams fat; ${ }^{8}$ Amita $^{\circledR}$, Coca-Cola Hellas S.A., Greece; $250 \mathrm{ml}=133 \mathrm{kcal}, 0.8$ grams protein, 33 grams carbohydrates. 
Table 2. Anthropometric characteristics and dietary habits of participants at baseline ${ }^{1}$

\begin{tabular}{|l|c|}
\hline Age (years) & $46 \pm 3$ \\
\hline Sex $(\mathrm{n}-$ male / female) & $5 / 12$ \\
\hline Height $(\mathrm{cm})$ & $167 \pm 0.02$ \\
\hline Body weight $(\mathrm{kg})$ & $93 \pm 4$ \\
\hline Body mass index $\left(\mathrm{kg} / \mathrm{m}^{2}\right)$ & $34 \pm 1$ \\
\hline
\end{tabular}

Dietary intake at baseline from 24-hour recall

\begin{tabular}{|l|c|}
\hline Energy (Kjoule) & $8545 \pm 360$ \\
\hline Protein (g) & $99 \pm 12$ \\
\hline Protein (\%) & $208 \pm 13$ \\
\hline Carbohydrates (g) & 40 \\
\hline Carbohydrates (\%) & $98 \pm 8$ \\
\hline Total fat (g) & 42 \\
\hline Total fat (\%) & $31 \pm 3$ \\
\hline Saturated fat (g) & $44 \pm 4$ \\
\hline Monounsaturated fat (g) & $12 \pm 1$ \\
\hline Polyunsaturated fat (g) & $21 \pm 2$ \\
\hline Total Fiber (g) & $294 \pm 34$ \\
\hline Cholesterol (mg) & \\
\hline Sodium (mg) & \\
\hline
\end{tabular}

${ }^{1}$ All values are means \pm SEM. 
Table 3. Anthropometric characteristics of participants at the beginning and at the end of a high protein, low fat (HP-LF) and a low protein, high fat diet (LP-HF) dietary intervention $(\mathrm{n}=17)^{1}$

\begin{tabular}{|c|c|c|c|c|c|c|c|}
\hline & \multicolumn{2}{|c|}{$\begin{array}{l}\text { LP-HF Diet } \\
(n=17)\end{array}$} & $P^{2}$ & \multicolumn{2}{|c|}{$\begin{array}{c}\text { HP-LF Diet } \\
(n=17)\end{array}$} & $P^{2}$ & $\begin{array}{l}P^{3} \text { for } \\
\text { betwe }\end{array}$ \\
\hline & Baseline & End & & Baseline & End & & \\
\hline $\begin{array}{l}\text { Body weight } \\
(\mathrm{kg})\end{array}$ & $93 \pm 4$ & $90 \pm 4$ & $<0.001$ & $92 \pm 4$ & $89 \pm 4$ & $<0.001$ & 0.800 \\
\hline BMI $\left(\mathrm{kg} / \mathrm{m}^{2}\right)$ & $34 \pm 1$ & $33 \pm 1$ & $<0.001$ & $33 \pm 1$ & $32 \pm 1$ & $<0.001$ & 0.751 \\
\hline $\mathrm{WC}(\mathrm{cm})$ & $108 \pm 4$ & $104 \pm 3$ & $<0.001$ & $107 \pm 3$ & $105 \pm 3$ & 0.021 & 0.988 \\
\hline $\mathrm{HC}(\mathrm{cm})$ & $112 \pm 3$ & $111 \pm 3$ & 0.010 & $112 \pm 3$ & $110 \pm 3$ & 0.001 & 0.968 \\
\hline $\begin{array}{l}\text { Fat Mass } \\
(\mathrm{Kg})^{4}\end{array}$ & $35 \pm 3$ & $33 \pm 3$ & 0.004 & $34 \pm 3$ & $31 \pm 3$ & $<0.001$ & 0.774 \\
\hline $\begin{array}{l}\text { Fat-free Mass } \\
(\mathrm{Kg})\end{array}$ & $58 \pm 3$ & $57 \pm 3$ & 0.004 & $57 \pm 3$ & $57 \pm 3$ & 0.196 & 0.945 \\
\hline $\begin{array}{l}\text { Water Mass } \\
\text { (lt) }\end{array}$ & $43 \pm 2$ & $42 \pm 2$ & 0.039 & $43 \pm 2$ & $43 \pm 2$ & 0.155 & 0.796 \\
\hline
\end{tabular}

${ }^{1}$ Values are means \pm SEM. Each dietary intervention lasted for 4 weeks. Abbreviations: BMI, body mass index; WC, waist circumference; HC, hip circumference ${ }^{2}$ Derived by using Student's paired $t$ test 
${ }^{3} \mathrm{P}$ for between-diet groups comparisons derived by using repeated measures analysis of variance. There was a significant main effect of time $(\mathrm{P}<0.001)$, but there was no significant main effect of diet or time-by-diet interaction.

${ }^{4}$ Body composition values were derived from multifrequency bioimpedance analysis Table 4. Blood pressure and biochemical parameters at the beginning and at the end of a high protein, low fat (HF-LF) and a low-protein, high fat (LP-HF) dietary intervention ${ }^{1}$

\begin{tabular}{|c|c|c|c|c|c|c|c|}
\hline & \multicolumn{2}{|c|}{$\begin{array}{c}\text { LP-HF Diet } \\
(n=17)\end{array}$} & $P^{2}$ & \multicolumn{2}{|c|}{$\begin{array}{c}\text { HP-LF Diet } \\
(n=17)\end{array}$} & \multirow[t]{2}{*}{$P^{2}$} & \multirow{2}{*}{$\begin{array}{l}P^{3} \text { for } \\
\text { between } \\
\text { diet }\end{array}$} \\
\hline & Baseline & End & & Baseline & End & & \\
\hline $\begin{array}{l}\text { Fasting } \\
\text { Glucose } \\
(\mathrm{mmol} / \mathrm{l})\end{array}$ & $7.5 \pm 0.3$ & $6.5 \pm 0.3$ & 0.04 & $7.1 \pm 0.2$ & $6.3 \pm 0.2$ & $<0.001$ & 0.498 \\
\hline $\begin{array}{l}\text { Fasting } \\
\text { Insulin } \\
(\mu \mathrm{UI} / \mathrm{ml})\end{array}$ & $10 \pm 1$ & $10 \pm 1$ & 0.551 & $9 \pm 2$ & $8 \pm 2$ & 0.234 & 0.652 \\
\hline HOMA-R & $6.3 \pm 1.0$ & $5.5 \pm 1.1$ & 0.056 & $5.5 \pm 0.9$ & $4.7 \pm 0.9$ & 0.022 & 0.527 \\
\hline $\begin{array}{l}\text { Systolic BP } \\
(\mathrm{mmHg})^{4}\end{array}$ & $134 \pm 4$ & $130 \pm 3$ & 0.043 & $134 \pm 4$ & $122 \pm 3$ & $<0.001$ & $<0.001$ \\
\hline $\begin{array}{l}\text { Diastolic BP } \\
(\mathrm{mmHg})^{5}\end{array}$ & $80 \pm 2$ & $77 \pm 1$ & 0.111 & $86 \pm 3$ & $78 \pm 2$ & $<0.001$ & $<0.001$ \\
\hline $\begin{array}{l}\text { TC } \\
(\mathrm{mmol} / \mathrm{l})\end{array}$ & $5.5 \pm 0.1$ & $4.9 \pm 0.2$ & 0.01 & $5.6 \pm 0.3$ & $4.9 \pm 0.1$ & 0.001 & 0.794 \\
\hline
\end{tabular}




\begin{tabular}{|c|c|c|c|c|c|c|c|}
\hline $\begin{array}{l}\text { TG } \\
(\mathrm{mmol} / \mathrm{l})\end{array}$ & $1.9 \pm 0.2$ & $1.5 \pm 0.1$ & $<0.001$ & $1.7 \pm 0.1$ & $1.2 \pm 0.1$ & 0.013 & 0.042 \\
\hline $\begin{array}{l}\text { HDL } \\
(\mathrm{mmol} / \mathrm{l})\end{array}$ & $1.1 \pm 0.1$ & $1.1 \pm 0.0$ & 0.073 & $1.2 \pm 0.1$ & $1.1 \pm 0.1$ & $<0.001$ & 0.777 \\
\hline $\begin{array}{l}\text { LDL } \\
(\mathrm{mmol} / \mathrm{l})\end{array}$ & $3.5 \pm 0.1$ & $3.2 \pm 0.2$ & 0.055 & $3.7 \pm 0.2$ & $3.2 \pm 0.2$ & 0.007 & 0.985 \\
\hline
\end{tabular}

${ }^{1}$ All values are means \pm SEM. Each dietary intervention lasted for 4 weeks. Abbreviations:

HOMA-R, homeostasis model assessment - insulin sensitivity at the fasting state; BP, blood pressure; TC, total cholesterol; TG, triglycerides; HDL, high density lipoprotein cholesterol;

LDL, low density lipoprotein cholesterol.

${ }^{2}$ Derived by using Student's paired $t$ test

${ }^{3} \mathrm{P}$ for between-diet groups comparisons derived by using repeated measures analysis of variance. There was a significant main effect of time for all variables listed, $\mathrm{P}<0.05$.

${ }^{4}$ Significant time-by-diet interaction, $\mathrm{P}=0.001$.

${ }^{3}$ Significant main effect of diet, $\mathrm{P}=0.048$ and significant time-by-diet interaction, $\mathrm{P}<0.001$. 
Table 5. Areas under the curve (AUC) and incremental area under the curve (IAUC) for glucose and insulin and insulin sensitivity in the post-absorptive period following the consumption of a standard test meal at the beginning and at the end of a high protein, low fat (HP-LF) and a low protein, high fat (LP-HF) dietary intervention ${ }^{1}$

\begin{tabular}{|c|c|c|c|c|c|c|c|}
\hline & \multicolumn{2}{|c|}{$\begin{array}{l}\text { LP-HF Diet } \\
\quad(n=17)\end{array}$} & \multirow[t]{2}{*}{$P^{2}$} & \multicolumn{2}{|c|}{$\begin{array}{c}\text { HP-LF Diet } \\
(n=17)\end{array}$} & \multirow[t]{2}{*}{$P^{2}$} & \multirow{2}{*}{$\begin{array}{c}P^{3} \text { for } \\
\text { between } \\
\text { diet }\end{array}$} \\
\hline & Baseline & End & & Baseline & End & & \\
\hline $\begin{array}{l}\text { Glucose } \\
\text { AUC } \\
\left(\mathrm{mmol}^{-1}\right. \\
\left.\cdot 180 \mathrm{~min}^{-1}\right)\end{array}$ & $9.0 \pm 0.9$ & $7.4 \pm 0.8$ & 0.003 & $8.0 \pm 0.7$ & $6.5 \pm 0.6$ & 0.002 & 0.412 \\
\hline $\begin{array}{l}\text { Glucose } \\
\text { IAUC } \\
\left(\mathrm{mmol}^{-1}\right. \\
\left.\cdot 180 \mathrm{~min}^{-1}\right)\end{array}$ & $485 \pm 78$ & $406 \pm 42$ & 0.046 & $373 \pm 96$ & $320 \pm 83$ & 0.047 & 0.393 \\
\hline $\begin{array}{l}\text { Insulin } \\
\text { AUC } \\
\left(\mu \mathrm{UI}^{-1} \cdot 180\right. \\
\left.\min ^{-1}\right)\end{array}$ & $\begin{array}{c}20111 \pm \\
3272\end{array}$ & $\begin{array}{c}15706 \pm \\
2671\end{array}$ & 0.776 & $\begin{array}{c}15053 \pm \\
4175\end{array}$ & $\begin{array}{c}10649 \pm \\
2846\end{array}$ & 0.011 & 0.148 \\
\hline $\begin{array}{l}\text { Insulin } \\
\text { IAUC }\left(\mu \mathrm{UI}^{-}\right.\end{array}$ & $\begin{array}{c}18237 \pm \\
3113\end{array}$ & $\begin{array}{c}13966 \pm \\
2556\end{array}$ & 0.80 & $\begin{array}{c}13456 \pm \\
3732\end{array}$ & $\begin{array}{c}9217 \pm \\
2463\end{array}$ & 0.01 & 0.148 \\
\hline
\end{tabular}




\begin{tabular}{|l|l|l|l|l|l|l|l|}
\hline${ }^{1} \cdot 180 \mathrm{~min}^{-1}$ ) & & & & & & & \\
\hline Insulin & $3 \pm 1$ & $4 \pm 1$ & 0.148 & $2.7 \pm 0.4$ & $4 \pm 1$ & 0.001 & 0.907 \\
sensitivity $^{4}$ & & & & & & & \\
\hline
\end{tabular}

${ }^{1}$ All values are means \pm SEM. Each dietary intervention lasted for 4 weeks. Abbreviations:

AUC, area under the curve; IAUC, incremental area under the curve. ${ }^{2}$ Derived by using Student's paired $t$ test.

${ }^{3} \mathrm{P}$ for between-diet groups comparisons derived by using repeated measures analysis of variance. There was a significant main effect of time for all variables listed, $\mathrm{P}<0.05$. ${ }^{4}$ Insulin sensitivity in the post-absorptive period was determined by the Matsuda \& Defronzo formula, $[10,000 /$ the square root of (fasting glucose $(\mathrm{mg} / \mathrm{dl}) \mathrm{X}$ fasting insulin $(\mu \mathrm{U} / \mathrm{ml}) \mathrm{X}$ (mean two hour postprandial glucose X mean two hour postprandial insulin]. 
$\checkmark$ Low Protein, High Fat Diet Baseline

$-\square \quad$ Low Protein, High Fat Diet End

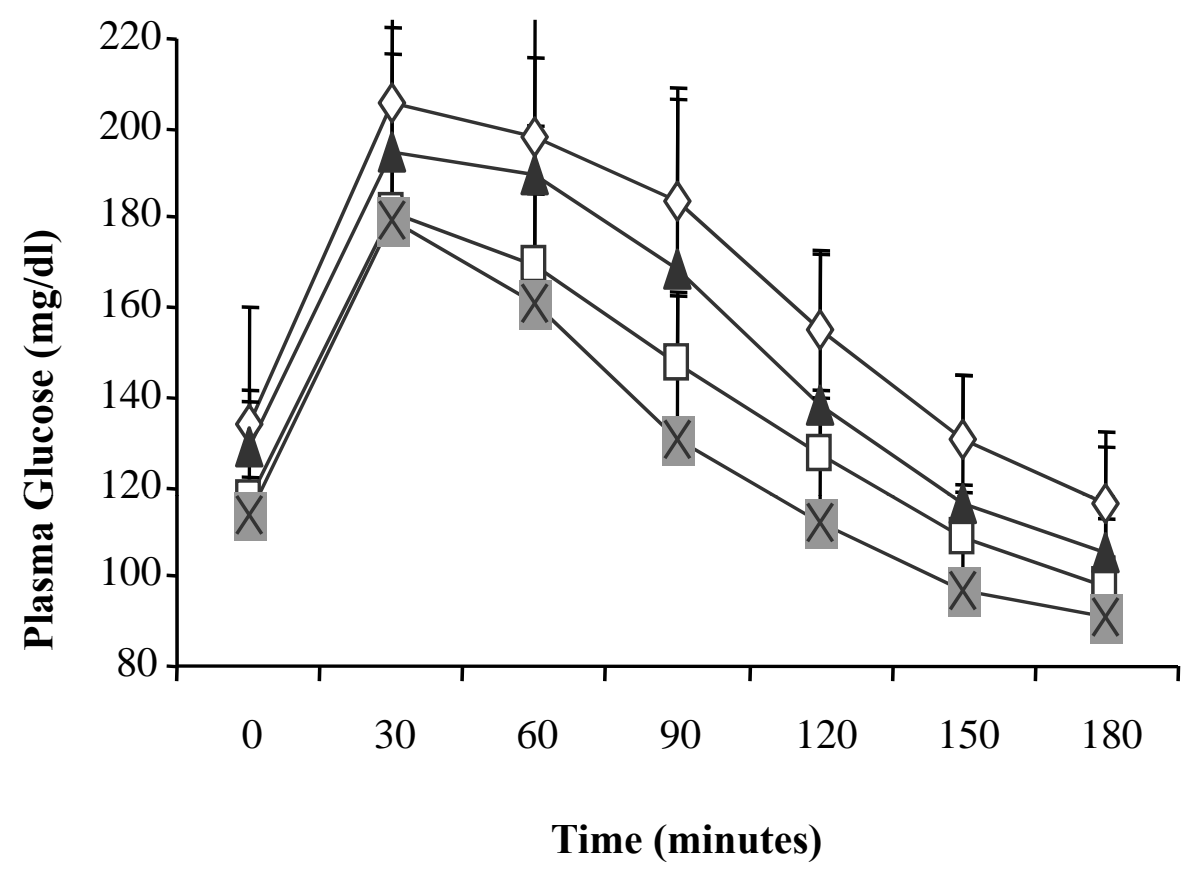

$\checkmark$ High Protein, Low Fat Diet Baseline

$-\times-$ High Protein, Low Fat Diet End

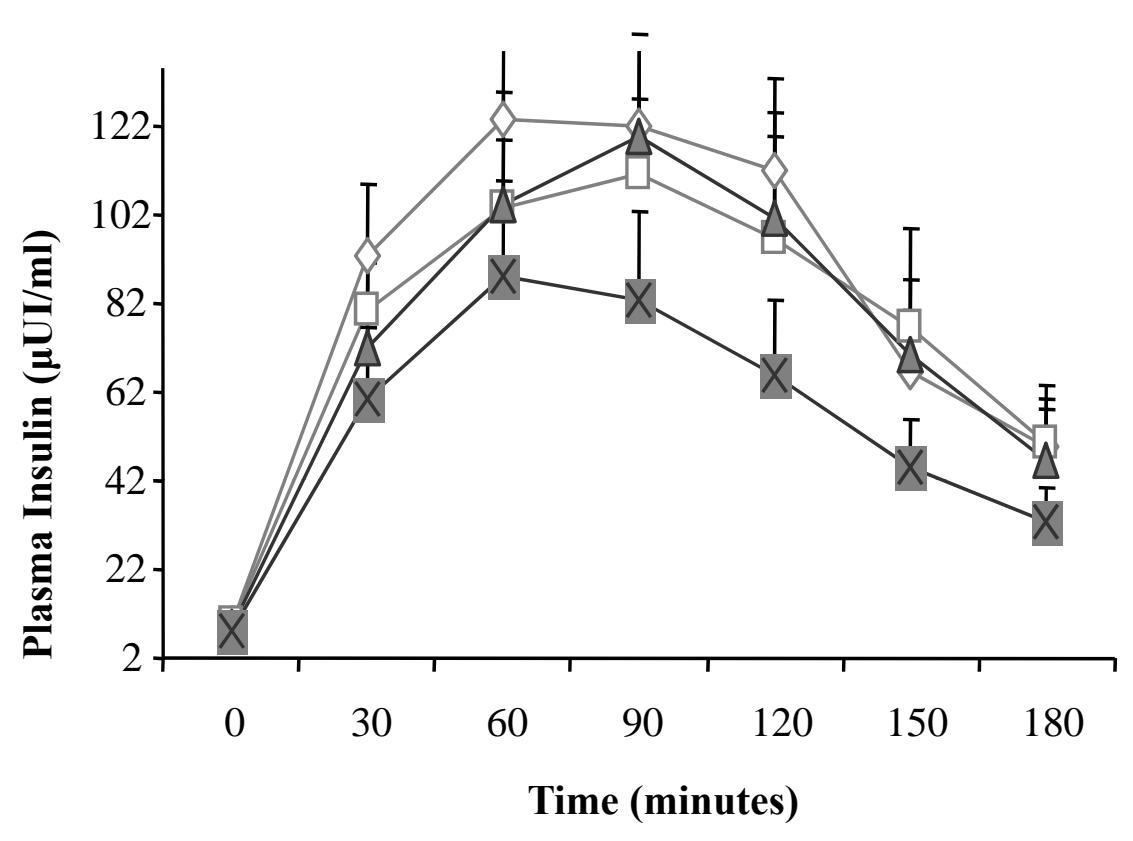

